\title{
ANALÝZA SLUŽIEB POSKYTOVANÝCH BANKAMI K OSOBNÉMU ÚČTU KLIENTA
}

\author{
Lucia Švábová*
}

\section{Úvod}

Dobre rozvinutá trhová ekonomika sa bez peňazí ako platobného prostriedku ani nedá predstavit'. Peniaze tu boli odjakživa a to $\mathrm{v}$ rôznych formách, záležalo na dobe, v ktorej sa žilo. Dnes ide doba opät' dopredu a reklama na nás útočí zo všetkých strán. Jej obsahom sú marketingové t’ahy komerčných bánk, usilujúcich sa prilákat' čo najviac klientov. Pri výbere vhodnej banky sa pre klienta stáva rozhodujúcim najmä ponuka jej produktov, profesionalita banky, dostupnost' a v neposlednom rade aj výška poplatkov a úrokových sadzieb. Nakol'ko služby a produkty sú vel'mi rozdielne, každý klient by si mal predtým, ako sa rozhodne s bankou spolupracovat', jednotlivé banky a ich produkty porovnat', čo je aj ciel'om tohto článku.

\section{Bežný účet klienta}

V polovici roka 2007 vypracovala Slovenská banková asociácia Etický kódex bánk v oblasti ochrany spotrebitel'a. Kódex je súbor etických pravidiel na ochranu spotrebitel'a, ktorým sa zúčastnené banky zaväzujú poskytovat' finančné služby klientom na vysokej úrovni, dodržiavajúc zásady slušnosti a transparentnosti podnikania [2]. Vzt'ahuje sa na bežné účty, vkladové účty a vklady, sporiace účty, služby platobného styku, elektronické bankovníctvo, debetné a kreditné karty, spotrebné úvery, úvery na bývanie, hypotekárne úvery, stavebné sporenie a investičné služby. V kapitole 7 etického kódexu je rozpracovaná problematika týkajúca sa bežného účtu. Banky sa v nej zaväzujú, že otvoria bežný účet pre klientov, ktorí o to prejavia záujem a splnia podmienky na otvorenie požadovaného typu bežného účtu [1].

Ku bežnému účtu svojich klientov banky ponúkajú rôzne služby, no ked’že každá banka sa usiluje získat' klientov čo najviac, paleta služieb a produktov vzt'ahujúcich sa $\mathrm{k}$ bežným účtom je vel'mi rôznorodá a $\mathrm{v}$ dnešnej dobe je už samozrejmost'ou, že jeden a ten istý klient má otvorené účty $\mathrm{v}$ rôznych bankách [1]. K účtu klient môže mat' platobnú kartu, elektronické bankovníctvo, v prípade potreby môže účet prečerpat'. Poplatok podl'a cenníka banky platí paušálne za vedenie účtu a za každú operáciu, ktorú vykoná, alebo službu, ktorú mu banka poskytne, platí zvlášt'. Bežné účty ponúkajú všetky banky, v súčasnosti sa však viac do popredia dostávajú balíčky služieb. Princíp balička spočíva v tom, že balíček obsahuje okrem bežného účtu aj niektoré operácie a služby, ktoré sú zahrnuté v jeho cene. Ak ich klient nevyčerpá, zaplatí aj tak plnú cenu balíka. Ak ich vyčerpá a niektoré operácie či služby

\footnotetext{
* RNDr. Lucia Švábová, Žilinská univerzita, Fakulta PEDaS, Katedra KMaHI, tel.: +421415133257

e-mail: lucia.svabova@fpedas.uniza.sk
} 
využije navyše, okrem paušálnej ceny za balík platí aj všetky realizované operácie navyše. Pri balíčkoch služieb je teda vel'mi dôležité vybrat' si ten správny. Banky ich totiž majú v ponuke niekol'ko - každý obsahuje niečo iné, za inú cenu [1].

V nasledujúcom texte článku sa budeme zaoberat' porovnaním jednotlivých služieb, ktoré banky k bežnému účtu ponúkajú. Ku tejto analýze sme si zvolili 5 bánk: Slovenská sporitel’ňa, Tatra banka, Československá obchodná banka, Všeobecná úverová banka a nová banka na slovenskom trhu - mBank.

\section{Charakteristika vybraných bánk}

Slovenská sporitel’ňa, a.s. je banka s najdlhšou tradíciou sporitel'níctva na Slovensku. Je v súčasnosti najväčšou komerčnou bankou na Slovensku s úplnou devízovou licenciou a povolením na vykonávanie hypotekárnych bankových obchodov. Svojim klientom poskytuje širokú škálu produktov a služieb, od tradičných bežných účtov, rôzne typy vkladných knižiek, termínované vklady, úvery a moderné služby elektronického bankovníctva.

Tatra banka, a.s. vznikla ako prvá súkromná banka na Slovensku. Ako prvá zaviedla na trh novú službu - zasielanie výpisu z účtu prostredníctvom internetu. V d'alšom roku ponuku rozšírila o možnost' získat' informáciu o okamžitom stave účtu a zadávat' prevodné príkazy z účtu prostredníctvom telefonickej služby Dialog. V oblasti elektronických služieb rozšírila svoju ponuku o novú službu Mobil banking, ktorá umožňuje získavat' informácie o zostatku a pohyboch na účte ako aj zadávat' platobné príkazy prostredníctvom mobilného telefónu.

Československá obchodná banka, a.s. funguje od roku 1964. Ako jediná banka vo vtedajšom Československu poskytovala služby v oblasti financovania zahraničného obchodu. Dnes svoje služby poskytuje v širokej sieti pobočiek. Banka je na Slovensku súčast'ou silnej finančnej skupiny ČSOB, do ktorej patrí napr. aj poist'ovňa, stavebná sporitel'na, leasingová spoločnost', dôchodková správcovská spoločnost'.

V̌̃eobecná úverová banka, a.s. patrí medzi najziskovejšie banky na slovenskom trhu. Patrí jej popredné miesto na slovenskom trhu úverov, o čom svedčí aj medziročný nárast úverov poskytnutých klientom o 41\%. Na Slovensku má 160 pobočiek a 65 expozitúr, jednu pobočku má aj v Českej republike.

mBank, a.s. vstúpila na slovenský trh v novembri 2007. Je pobočkou zahraničnej banky Bre Bank, SA. Ponúka bežné účty, ktoré sú vedené bezplatne, sporiace účty, hypotéky a novinkou $\mathrm{v}$ tomto roku sú spotrebné úvery. Banka d’alej pripravuje Hypermarket investičných fondov a kreditné karty. Obchodnú siet' mBank tvoria Finančné centrá a mKiosky. Primárnym prevádzkovým a predajným kanálom je internet a telefón [1].

\section{Modeloví klienti vybraných bánk}

Paleta služieb, ktoré sú na slovenskom bankovom trhu poskytované jednotlivými bankami, je vel'mi rôznorodá. Pre analýzu sme si vytvorili tri modely:

1. Model študent - vysokoškolák do 26 rokov, ktorý predstavuje pre banky budúcu potenciálnu klientelu, ktorá tu raz bude mat' otvorený svoj bežný účet. Tento klient má záujem o využívanie služieb elektronického bankovníctva, výbery z bankomatu a chce mat' prehl'ad o pohyboch na svojom účte napríklad zasielaním sms, či e-mailu.

2. Model osoba - nepodnikatel' okolo 30 rokov, ktorého kreditný obrat na účte je minimálne 20000 Sk mesačne. Klient chce využívat' svoju platobnú kartu pri 
platbách v obchodoch, realizovat' čo najlacnejšie výbery z bankomatu, využívat' služby elektronického bankovníctva.

3. Model dôchodca - senior, ktorý má vo svojej banke otvorený účet, na ktorý mu pravidelne chodí dôchodok, prostredníctvom účtu platí napríklad SIPO, využíva platobnú kartu pri nákupoch atd'. [1].

Pre týchto vytvorených modelových klientov budeme vyberat' vhodnú alternatívu bežného účtu $\mathrm{v}$ jednotlivých bankách a služby, ktoré banky ku bežnému účtu ponúknu.

\section{Výber vhodnej alternatívy pre modelových klientov}

\section{Model študent - vysokoškolák}

a. Slovenská sporitel’ňa, a.s. ponúka účet SPOROžíro vysokoškolák, ktorý má charakter bežného účtu. Zriadenie účtu je bezplatné. V Slovenskej sporitel'ni je to ideálna vol'ba pre nášho modelového klienta, nakol'ko tento účet slúži na vklady a výbery peňažných prostriedkov, umožňuje prístup k peniazom a realizáciu platobného styku s využitím moderných bankových technológií. Všetky služby spojené s vedením účtu poskytuje SLSP bez poplatkov. Navyše, SLSP vytvorila študentský klub, prostredníctvom ktorého získa študent rôzne výhody a zl'avy v obchodoch, pri cestovaní, atd'.

b. Tatrabanka, a.s. pre študentov ponúka balík služieb s názvom TatraAcademy, ktorý zahíňa Internet banking, Mobil banking, telefonickú službu Dialog. Poplatok za balík je 11 Sk mesačne. Výbery z bankomatu, platby kartou, používanie služby Internet banking sú bezplatné $v$ neobmedzenom množstve. Účet je vedený bez povinného minimálneho zostatku a ako bonus si študent môže vybrat' dizajn svojej platobnej karty.

c. ČSOB študentský účet - FUN účet je určený pre mladých l'udí vo veku 15 - 28 rokov. Zriadenie účtu je bez poplatku, študent môže využívat' služby elektronického bankovníctva, mesačne má k dispozícii 5 sms správ o zostatku a pohyboch na účte. Vedenie účtu je zadarmo. Navyše klient získa študentský preukaz ISIC, ktorý ho oprávňuje k získaniu rôznych zliav a výhod na Slovensku aj v zahraničí.

d. Na rozdiel od predchádzajúcich troch bánk, Všeobecná úverová banka, a.s. neobmedzuje svoje Start konto podmienkou štúdia na vysokej škole. Účet môžu získat' všetci mladí l'udia vo veku 15 - 26 rokov. Mesačný poplatok je 9 Sk a zahŕňa vedenie účtu, službu Kontakt, Internet banking, Mobil banking, výpis z účtu zasielaný štvrt'ročne, vydanie medzinárodnej platobnej karty. Navyše banka klientovi vráti mesačný poplatok $\mathrm{v}$ prípade, že zrealizuje mesačne minimálne 6 pohybov na svojom účte.

e. mBank, a.s. ponúka svoje mKONTO pre všetkých klientov bez ohl'adu na vek či zamestnanie. Služba Inkaso umožňuje klientom automaticky uhrádzat' pravidelné platby. mBank ponúka svoje služby výlučne elektronickou formou. Otvorenie účtu, vedenie účtu a všetky služby s ním spojené sú bez poplatku.

Vybrané banky ponúkajú rôzne druhy balíkov a služieb s rôznym obsahom a odlišnou cenou, ktorá však nepredstavuje ani pre túto skupinu klientov vel'ké náklady. Rozhodujúce môžu skôr byt' výhody, ktoré banka k účtu ponúkne.

\section{Model osoba-nepodnikatel'}

a. Bežný účet SPOROžíro v SLSP je určený pre tých klientov, ktorí na manipuláciu so svojim účtom využivajú len pár operácií. Za každú operáciu ako je bezhotovostný vklad na účet, realizácia platobného príkazu, výber z bankomatu, platba kartou platia zvlášt' poplatok vo výške 4 Sk. V prípade, že klient potrebuje využívat' tieto služby 
častejšie, môže si vybrat' z jedného z troch balíkov služieb: Balík Extra, Balík Extra Plus alebo Balík Exclusive, ktorých mesačný poplatok je vo výške 49 Sk, 89 Sk a 199 Sk.

b. V Tatra banke, a.s. si noví klienti môžu zriadit' už len účet s balíkom služieb, zriadenie samostatného účtu nie je možné. Pre nášho modelového klienta, ktorý chce využívat' služby elektronického bankovníctva, je vhodný Balík TatraDynamic, ktorý ponúka 15 transakcií bez poplatku, zadávanie trvalých príkazov a inkás cez služby Internet banking a Dialog. Mesačný poplatok za tento balík služieb je 79 Sk.

c. ČSOB, a.s. vytvorila pre bežných klientov bežný účet, ku ktorému ponúka tri balíčky služieb: Pohoda, Pohoda plus a Extra pohoda. Pre nášho modelového klienta by bol vhodný balík Pohoda, ktorého mesačný poplatok je najviac 66 Sk, výška poplatku sa odvíja od množstva peňazí, ktoré má klient v banke investované. Zriadenie a zmeny trvalých príkazov a inkás, elektronické platobné príkazy, platby kartou doma aj v zahraničí, výbery $\mathrm{z}$ bankomatov sú obsiahnuté $\mathrm{v}$ tomto balíku bez obmedzenia počtu.

d. VÚB, a.s. ponúka svojim klientom Flexiúčet, ktorý obsahuje služby, ktoré si klient sám vyberá a podl'a toho sa určuje cena balíka. Služby je možné kedykol'vek pridat' alebo vymenit' za iné. Pri výbere jedného produktu z ponuky je cena balíka 37 Sk za mesiac, pri výbere 2 a 3 produktov je to 57 Sk za mesiac. Klient má navyše možnost' získat' mesačný poplatok spät' po splnení podmienok stanovených bankou.

Ak si klient vyberá z týchto ponúk podl'a služieb elektronického bankovníctva, v najlacnejších balíkoch služieb ho ponúkajú ČSOB (66 Sk mesačne), SLSP (49 Sk mesačne) a VÚB (57 Sk mesačne). Ak vyberáme vhodný typ účtu podla výberu z bankomatov vlastnej banky, výhodný je účet v ČSOB, ktorá ponúka neobmedzený počet výberov z bankomatu zadarmo a neúčtuje si ani účtovnú položku. Tatra banka a VÚB si za výber z bankomatu účtuje len túto účtovnú položku. Slovenská sporitel'ňa zvýhodňuje výber z bankomatu vlastnej banky až v druhom drahšom balíku. V prípade, že sa chceme riadit' kritériom výšky poplatkov za platbu kartou, už v najlacnejšom balíku si za platbu kartou neúčtuje nič ČSOB (v neobmedzenom množstve), SLSP, v ostatných bankách klient platí účtovnú položku.

\section{Model senior}

a. SPOROžíro senior je bežný účet v SLSP určený pre poberatel'ov dávok dôchodkového zabezpečenia. Vedenie účtu je za 10 Sk mesačne, všetky d'alšie obraty na účte, trvalé príkazy, platby kartou atd’. sú spoplatnené osobitne podl’a cenníka banky.

b. Tatra banka, a.s. neponúka pre seniorov žiadny špecializovaný typ účtu.

c. ČSOB, a.s. podobne ako Tatra banka nemá pre seniorov vyvinutý žiadny špeciálny typ účtu.

d. Všeobecná úverová banka, a.s. ponúka účet $\boldsymbol{V U} \boldsymbol{B}$ Senior, ktorý je určený tým klientom, ktorí si chcú zasielat' svoje dôchodkové dávky na svoj účet. Mesačný poplatok je vo výške 9 Sk a zahŕňa vedenie účtu, vydanie platobnej karty, výpis z účtu zasielaný štvrt'ročne, zadávanie a zmenu trvalých príkazov a inkás.

Seniori si teda môžu zriadit' svoj účet v Slovenskej sporitel'ni alebo v ČSOB, ktoré im balíčky služieb v podobnej cene zostavili podl'a ich potrieb. Tiež je možnost' otvorenia si účtu v mBank, ktorý je úplne bez poplatkov pre všetkých klientov. 


\section{Záver}

Balík služieb k bežnému účtu si treba vybrat' na mieru. Klient si musí vypočítat' priemerný počet jednotlivých operácií, ktoré uskutočnil za posledné $2-3$ mesiace a porovnat', kol'ko platí nad limit svojho doterajšieho balíka a či mu iný balík alebo iná banka neponúknu niečo, čo by lepšie vyhovovalo jeho potrebám. Ďalším krokom je preskúmat' svoje správanie sa ako klienta. Niekto si radšej priplatí za luxus, aby sa nemusel zamýšl'at' nad tým, kol'ko operácií mesačne robí a či vyberá hotovost' z bankomatu svojej banky alebo od konkurencie. V tomto prípade ale nemôže očakávat', že dostane balík v najnižšej cenovej kategórii.

Ako sme očakávali, banky ponúkajú najvýhodnejšie účty pre študentov. Navyše študentom ku zriadeniu účtu ponúkajú aj d’alšie výhody a zl'avy v obchodoch, pri cestovaní atd'. Príkladom toho je Slovenská sporitel'ňa a Československá obchodná banka.

Bežní klienti majú poväčšine dve možnosti. Bud' si založia v banke bežný účet a za každú službu budú platit' zvlášt' alebo stavia na dnešný trend - balíček služieb, ktorý si vyberú presne podl'a svojich potrieb. Nie každá banka však ponúka Internet banking alebo Mobil banking už k tomu najlacnejšiemu balíčku.

\section{Literatúra}

[1] BAVLNOVÁ , K.: Analýza služieb poskytovaných bankami k osobnému účtu klienta, Bakalárska práca, Žilinská univerzita v Žiline, Fakulta PEDaS, Katedra spojov, 2008.

[2] Štatistiky Slovenskej bankovej asociácie. [online], [citované 2008-04-17]. Dostupné na: < http://www.sbaonline.sk/files/subory/analyzy/verejne/monica-07.pdf>

[3] Etický kódex bánk. [online], [citované 2007-12-14]. Dostupné na: $<\mathrm{http}$ ://www.sbaonline.sk/sk/o-nas/eticky-kodex/>

[4] Internetová stránka Slovenskej sporitel’ne, a.s. 2008. [online], [citované 2008-09-02]. Dostupné na $<$ www.slsp.sk>

[5] Internetová stránka Tatrabanky, a.s. 2008. [online], [citované 2008-09-02]. Dostupné na $<$ www.tatrabanka.sk>

[6] Internetová stránka Československej obchodnej banky, a.s. 2008. [online], [citované 2008-09-02]. Dostupné na <www.csob.sk>

[7] Internetová stránka V̌seobecnej úverovej banky, a.s. 2008. [online], [citované 2008-0902]. Dostupné na $<$ www.vub.sk $>$

[8] Internetová stránka mBank, a.s. 2008. [online], [citované 2008-09-02]. Dostupné na $<$ www.mbank.sk> 